\title{
Presacral Teratocarcinoma Presenting as Anal Fistula and Rectal Adenocarcinoma: A Unique Case Presentation and Literature Review
}

\author{
S.P. Ho ${ }^{a}$ J.S. Wang ${ }^{a}$ H.H. Tseng ${ }^{a}$ T.M. King ${ }^{b}$ \\ Departments of ${ }^{\mathrm{a}}$ Pathology, and ${ }^{\mathrm{b}}$ Colorectal Surgery, Kaohsiung Veterans \\ General Hospital, Kaohsiung, Taiwan
}

\section{Key Words}

Presacral teratoma - Anal fistula $\cdot$ Rectal adenocarcinoma - Somatic malignancy arising from teratoma $\cdot$ Teratoma with malignant transformation

\begin{abstract}
Somatic malignancy arising from presacral or retroperitoneal primary teratoma is extremely rare. We report the case of a 37-year-old male patient with adenocarcinoma of respiratory type arising from primary presacral teratoma, but which first presented as anal fistula and rectal adenocarcinoma. The two tumors show the same morphology and immunophenotype (CK7-CK20+CDx2+). Malignant adenocarcinoma transformations from the normal respiratory epithelium are also found. To the best of our knowledge, this is the second case of respiratory type adenocarcinoma arising from primary presacral mature cystic teratoma.
\end{abstract}

\section{Case Presentation}

A 37-year-old male with no significant medical history presented with perianal pain. Anal fistula was initially supposed but the pathology of fistulectomy revealed adenocarcinoma. Digital examination showed a palpable mass. Endoscopic examination revealed an ulcerative mass located 3 $\mathrm{cm}$ above the anal verge. After the diagnosis of rectal adenocarcinoma, the patient underwent abdomino-peritoneal resection of the rectum. Pathologic examination of the rectal specimen revealed a low-grade adenocarcinoma, stage I. The patient received regular follow-up after the operation.

Four years later, the patient complained of frequent lower back pain lasting for 2 weeks. An image study was conducted which disclosed a large presacral cyst, measuring $7.8 \times 7 \times 5.4 \mathrm{~cm}$ in its greatest dimension (fig. 1). An elevated serum carcinoembryonic antigen level of 10.4, was also noted. On suspicion of recurrent rectal cancer, the patient received anterior resection and presacral cyst excision. Microscopic examination of the anterior resection specimen revealed a teratocarcinoma 
composed of mature cystic teratoma and adenocarcinoma (fig. $2 \mathrm{~d}$, fig. $3 \mathrm{a}$ ). The teratoma component of the teratocarcinoma consisted of gastrointestinal mucosa (fig. 2a), cartilage (fig. 2b), pseudostratified respiratory epithelium (fig. 2c), and pancreas tissue. The rectum showed extensive ulceration with transmural inflammation and fibrosis. A residual low-grade adenocarcinoma was noted which was localized under the mucosal layer of the rectum. Juxtaposition of the pseudostratified respiratory epithelium of the teratoma and the neoplastic cells of the adenocarcinoma was identified (inset in fig. 3a). By immunohistochemistry, the neoplastic cells of the adenocarcinoma were negative for cytokeratin-7 (CK7) and positive for CK20 (CK7-CK20+) (fig. 3b, c). The adjacent juxtaposed respiratory epithelium had immunophenotype of CK7+CK20- (fig. 3b, c) [1]. The result of the immunohistochemistry stain for caudal related homeodomain transcription 2 (CDX2) was positive in the neoplastic cells of the adenocarcinoma but negative in those of the adjacent respiratory epithelium (fig. 3d).

To clarify whether the original rectal adenocarcinoma was actually the adenocarcinoma component of the teratocarcinoma, the original computerized tomography scan image was reviewed and a $2.7-\mathrm{cm}$ presacral cystic lesion was found. Further studies of the cystic lesion were done. However, all cytology and biopsy specimen of the cyst showed negative findings. After reviewing the HE-stained slides of the original abdomino-peritoneal resection specimen, a benign respiratory epithelium was found in addition to the adenocarcinoma. The presence of the benign respiratory epithelium and presacral cyst strongly supports a diagnosis of teratocarcinoma with rectal invasion in the original diagnosis.

\section{Discussion}

Primary teratoma of the presacral area is extremely rare with an incidence of only $6-11 \%$ of all presacral tumors [2]. Metastasis from other origin, especially gonadal organ, should be excluded before a diagnosis of primary presacral teratoma is made [3]. Primary presacral or retroperitoneal neoplasm usually presents as a single mass, whereas metastasis from other site, such as testis, usually involves both sites of lymph nodes and peritoneum. In our case, gonadal origin or other primary sites had been excluded by positron emission tomography scans. The incidence of the somatic malignancy arising from presacral teratomas (presacral teratocarcinoma) is extremely rare. Table 1 summarizes our review of the English literature. The type of somatic malignancies reported in presacral teratocarcinoma include adenocarcinoma, squamous cell carcinoma and carcinoid tumor (table 1) [4-16]. Presacral teratocarcinoma presenting as a rectal adenocarcinoma complicated by an anal fistula has not been reported before.

The somatic malignancy arising from teratoma was resistant to chemo- and radiotherapy. A regimen of postoperative chemotherapy of presacral teratocarcinoma has not been established due to its rare incidence [13]. It is unknown whether the prognostic factors of ovarian teratocarcinoma, such as capsular invasion, capsular rupture, dissemination, ascites, adhesions and special differentiation of adenocarcinoma, can be applicable or not on the presacral ones [2]. Our patient received combined chemoradiotherapy and six courses of chemotherapy using folinic acid-fluorouracil-oxaliplatin after surgery. Only a $3 \times 2$-cm residual presacral cyst was identified on follow-up computerized tomography 9 months after the last surgery. Nine years after the original diagnosis of rectal cancer, the patient is alive with no evidence of recurrence.

In summary, we presented the first case report of presacral teratocarcinoma presenting as a rectal adenocarcinoma complicated by an anal fistula. What we learned 
from our case is that a diagnosis of presacral teratocarcinoma with rectal invasion should also be considered in a patient with rectal carcinoma complicated by an anal fistula. Pathologically, the presence of any benign ectopic tissue, such as respiratory epithelium, in a rectal cancer specimen should raise the suspicion of teratocarcinoma. The presence of a presacral cyst in the image study also indicated this diagnosis. 
Table 1. Somatic malignancy arising from presacral or retroperitoneal teratoma [4-16]

\begin{tabular}{|c|c|c|c|c|c|c|c|c|c|}
\hline Authors & Year & $\begin{array}{l}\text { Age/ } \\
\text { sex }\end{array}$ & Site & $\begin{array}{l}\text { Somatic } \\
\text { malignancy }\end{array}$ & Transition & $\begin{array}{l}\text { Local } \\
\text { invasion }\end{array}$ & Recurrence & $\begin{array}{l}\text { Postoperative } \\
\text { treatment }\end{array}$ & Prognosis \\
\hline Tezel & 1995 & & $\begin{array}{l}\text { Retro- } \\
\text { peritoneal }\end{array}$ & & & & & & \\
\hline Renato & 1996 & & $\begin{array}{l}\text { Retro- } \\
\text { peritoneal }\end{array}$ & & & & & & \\
\hline \multirow[t]{2}{*}{ Wang } & 2002 & $40 / \mathrm{M}$ & $\begin{array}{l}\text { Retro- } \\
\text { peritoneal }\end{array}$ & $\begin{array}{l}\text { Focal well- } \\
\text { differentiated } \\
\text { adenocarcinoma }\end{array}$ & Unknown & $\begin{array}{l}\text { Adjacent to } \\
\text { other organs } \\
\text { and LAP }\end{array}$ & $\begin{array}{l}\text { Local } \\
\text { recurrence } \\
\text { and } \\
\text { metastasis to } \\
\text { the rectum }\end{array}$ & Adjuvant C/T & \\
\hline & & $30 / \mathrm{M}$ & $\begin{array}{l}\text { Retro- } \\
\text { peritoneal }\end{array}$ & $\begin{array}{l}\text { Moderately } \\
\text { differentiated } \\
\text { adenocarcinoma }\end{array}$ & Unknown & $\begin{array}{l}\text { Invasion to the } \\
\text { adrenal gland } \\
\text { and adhesion to } \\
\text { the aortic wall }\end{array}$ & & $\mathrm{C} / \mathrm{T}$ and $\mathrm{R} / \mathrm{T}$ & $\begin{array}{l}\text { Died } 10 \text { months } \\
\text { after diagnosis }\end{array}$ \\
\hline Yamasaki & 2004 & $53 / F$ & $\begin{array}{l}\text { Retro- } \\
\text { peritoneal }\end{array}$ & Carcinoid & $\begin{array}{l}\text { Juxtaposed } \\
\text { to the } \\
\text { respiratory } \\
\text { type } \\
\text { epithelium }\end{array}$ & $\begin{array}{l}\text { Adhesion to } \\
\text { kidney but no } \\
\text { invasion }\end{array}$ & & No & $\begin{array}{l}31 \text { months free of } \\
\text { tumor }\end{array}$ \\
\hline Song & 2005 & $72 / F$ & $\begin{array}{l}\text { Retro- } \\
\text { peritoneal }\end{array}$ & $\begin{array}{l}\text { Mucinous } \\
\text { adenocarcinoma, } \\
\text { respiratory type }\end{array}$ & Yes & $\begin{array}{l}\text { Adhesion and } \\
\text { intraoperative } \\
\text { rupture }\end{array}$ & & & $\begin{array}{l}\text { Brain metastasis } \\
\text { after } 2 \text { months and } \\
\text { died } 4 \text { months } \\
\text { after diagnosis }\end{array}$ \\
\hline Leandros & 2005 & $47 / \mathrm{M}$ & $\begin{array}{l}\text { Retro- } \\
\text { peritoneal }\end{array}$ & Malignant & & No & & $\begin{array}{l}\text { Neoadjuvant } \\
\mathrm{C} / \mathrm{T}\end{array}$ & $\begin{array}{l}13 \text { months free of } \\
\text { tumor }\end{array}$ \\
\hline Chu & 2006 & $36 / F$ & $\begin{array}{l}\text { Retro- } \\
\text { peritoneal }\end{array}$ & $\begin{array}{l}\text { Signet-ring cell } \\
\text { type with focal } \\
\text { intestinal-type } \\
\text { adenocarcinoma }\end{array}$ & Yes & No & No & $\begin{array}{l}\text { Local C/T and } \\
\mathrm{R} / \mathrm{T}\end{array}$ & $\begin{array}{l}\text { Distant metastasis } \\
\text { to the neck lymph } \\
\text { nodes } 2 \text { months } \\
\text { after surgery }\end{array}$ \\
\hline Joseph & 2006 & $65 / F$ & $\begin{array}{l}\text { Retro- } \\
\text { peritoneal }\end{array}$ & $\begin{array}{l}\text { Squamous cell } \\
\text { carcinoma, well- } \\
\text { to poorly- } \\
\text { differentiated }\end{array}$ & & $\begin{array}{l}\text { Multiple } \\
\text { omental } \\
\text { seeding }\end{array}$ & Unknown & Unknown & Unknown \\
\hline Wang & 2008 & $47 / F$ & $\begin{array}{l}\text { Retro- } \\
\text { peritoneal }\end{array}$ & $\begin{array}{l}\text { Colonic-type } \\
\text { adenocarcinoma }\end{array}$ & Yes & No & No & No & $\begin{array}{l}18 \text { months free of } \\
\text { tumor }\end{array}$ \\
\hline Kim & 2009 & $45 / F$ & $\begin{array}{l}\text { Retro- } \\
\text { peritoneal, } \\
\text { presacral }\end{array}$ & $\begin{array}{l}\text { Mucinous } \\
\text { adenocarcinoma } \\
\text { with elevated } \\
\text { CA199 }\end{array}$ & Unknown & $\begin{array}{l}\text { Adhesion, local } \\
\text { invasion and } \\
\text { intraoperative } \\
\text { rupture }\end{array}$ & $\begin{array}{l}\text { Local } \\
\text { recurrence } \\
\text { with } \\
\text { metastasis }\end{array}$ & $\begin{array}{l}\text { Postoperative } \\
\mathrm{C} / \mathrm{T} \text { and } \mathrm{R} / \mathrm{T}\end{array}$ & $\begin{array}{l}\text { Abdominal wall } \\
\text { metastasis after } 8 \\
\text { and } 15 \text { months, } \\
\text { died } 19 \text { months } \\
\text { after surgery. } \\
\text { Died } 19 \text { months } \\
\text { after first diagnosis }\end{array}$ \\
\hline Terado & 2010 & $27 / \mathrm{M}$ & $\begin{array}{l}\text { Retro- } \\
\text { peritoneal }\end{array}$ & $\begin{array}{l}\text { Small intestinal } \\
\text { adenocarcinoma }\end{array}$ & Yes & No & No & No & $\begin{array}{l}18 \text { months free of } \\
\text { tumor }\end{array}$ \\
\hline McCawley & 2010 & $46 / F$ & $\begin{array}{l}\text { Retro- } \\
\text { rectal }\end{array}$ & $\begin{array}{l}\text { Colonic } \\
\text { adenocarcinoma }\end{array}$ & No & No & No & Unknown & Unknown \\
\hline $\begin{array}{l}\text { Present } \\
\text { case }\end{array}$ & 2012 & $37 / \mathrm{M}$ & Presacral & $\begin{array}{l}\text { Adenocarcinoma, } \\
\text { sinonasal } \\
\text { intestinal-type }\end{array}$ & Yes & $\begin{array}{l}\text { Invasion to the } \\
\text { rectum at } \\
\text { present }\end{array}$ & No & CCRT and C/T & $\begin{array}{l}\text { Residual small cyst } \\
\text { and alive after } 9 \\
\text { years }\end{array}$ \\
\hline
\end{tabular}




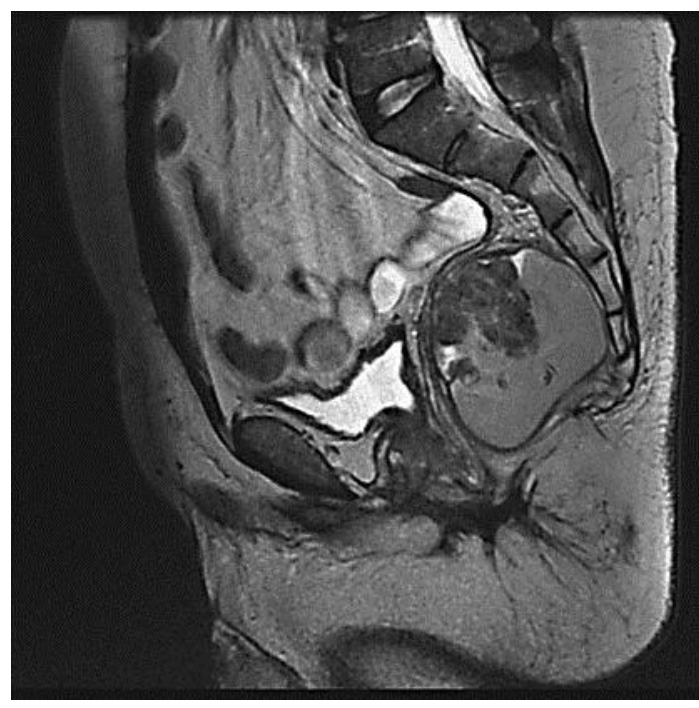

Fig. 1. Magnetic resonance imaging showing a 7.8-cm cystic lesion of the presacral area.
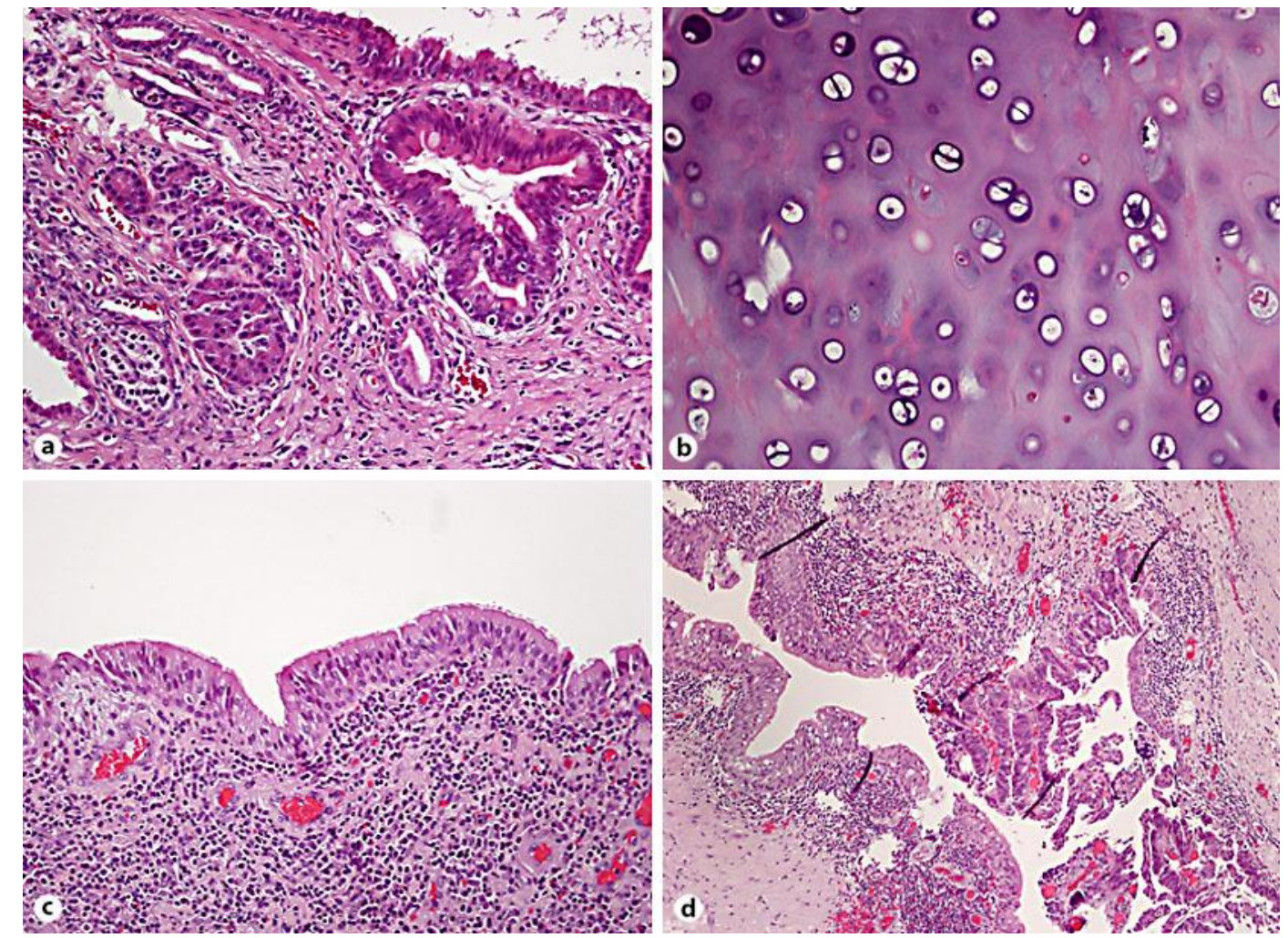

Fig. 2. Presacral lesion showing teratomatous components including gastrointestinal epithelium (a), cartilage (b), and respiratory epithelium (c). Transition between the respiratory epithelium of the teratoma and the dysplastic epithelium of the adjacent adenocarcinoma (d). 

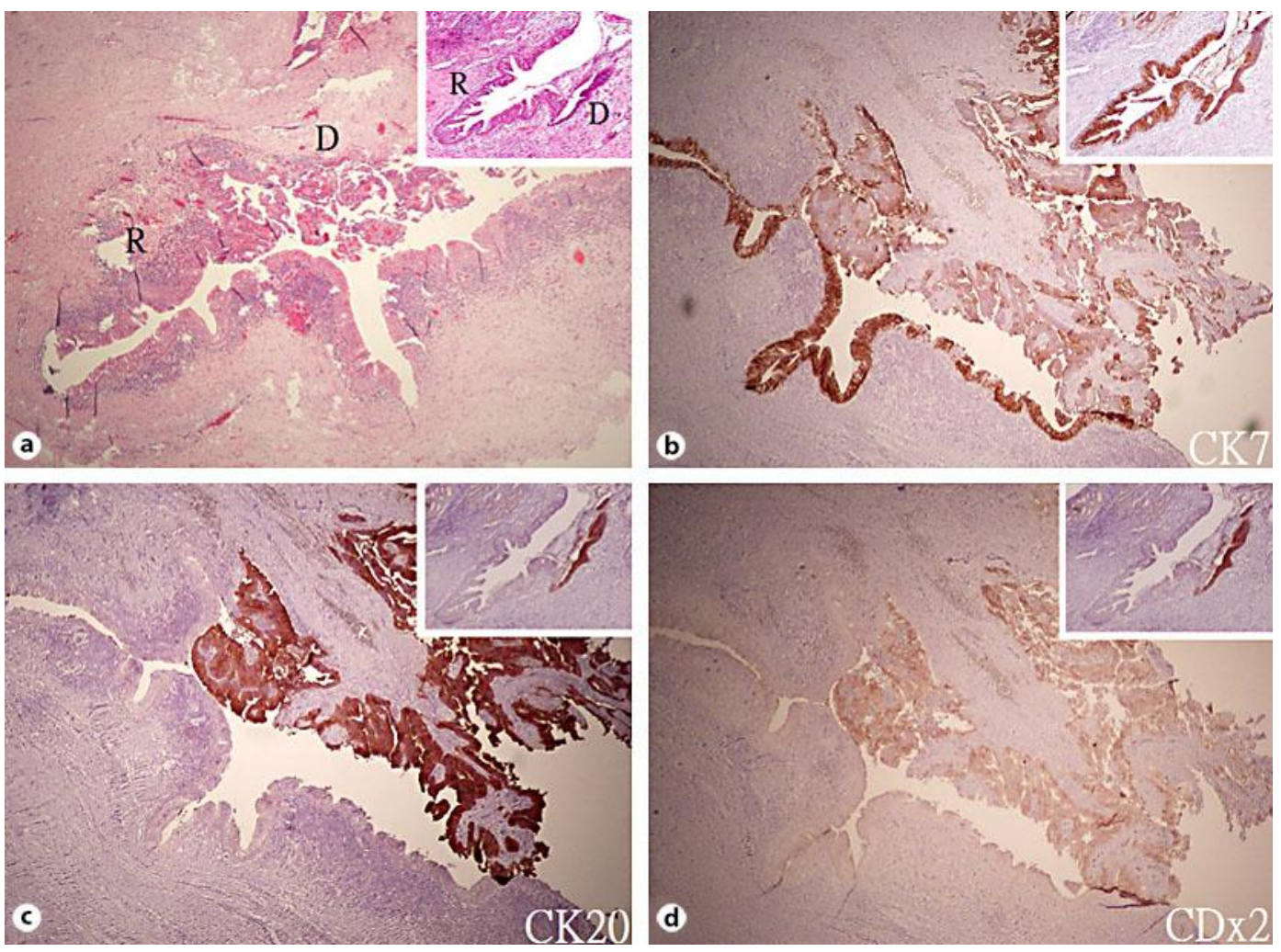

Fig. 3. Juxtaposition between the benign ciliated pseudostratified columnar epithelium (R) and the dysplastic epithelium (D) of the adenocarcinoma was identified in both the presacral teratocarcinoma (a) and the original rectal adenocarcinoma (a inset). The respiratory epithelium (R) shows

CK7+CK20-CDx2- immunophenotype (b-d), and the dysplastic epithelium (D) of the adenocarcinoma shows CK7+/-CK20+CDx2+/- immunophenotype (b-d). The dysplastic epithelium (D) of the original rectal cancer shows more intense CDX2 staining (d inset).

\section{References}

1 Barnes L, Eveson JW, Reichart P, Sidransky D: World Health Organization Classification of Tumours. Pathology and Genetics of Head and Neck Tumours. 2005, p 20-22.

$\checkmark 2$ Kim JH, Lee TS, Oh HK, Choi YS: A case of mucinous adenocarcinoma arising from retroperitoneal teratoma treated with chemoradiation. J Gynecol Oncol 2009;20:126-128.

3 Rosai J, et al: Rosai and Ackerman's Surgical Pathology, 10th Edition.

4 McCawley N, Hanly A, Solon G, Shilling C, Deasy J, Kay EW, McNamara DA: Adenocarcinoma arising in a retrorectal teratoma: Case report and review of the literature. Colorectal Disease 2011; The Association of Coloproctology of Great Britain and Ireland 2011, vol 13, pp e312-e313.

-5 Tezel E, Sare M, Edali N, Oguz M, Uluoglu O, Gökok NH: Retroperitoneal malignant teratoma. A case report. Mater Med Pol 1995;27:123-125.

6 Renato F, Paolo V, Girolamo M, Viganò L, Alessandro P, Claudio V, Cristina B, Lucio F, Riccardo M: Malignant retroperitoneal teratoma: case report and literature review. Acta Urol Belg 1996;64:49-54.

-7 Zamir G, Wexner SD, Pizov G, Reissman P: Primary presacral adenocarcinoma. Report of a case. Dis Colon Rectum 1998;41:1056-1058.

8 Wang LJ, Chu SH, Ng KF, Wong YC: Adenocarcinomas arising from primary retroperitoneal mature teratomas: CT and MR imaging. Eur Radiol 2002;12:1546-1549. 
9 Yamasaki T, Yagihashi Y, Shirahase T, Hashimura T, Watanabe C: Primary carcinoid tumor arising in a retroperitoneal mature teratoma in an adult. Int J Urol 2004;11:912-915.

10 Leandros E, Alexakis N, Konstadoulakis M, Albanopoulos K, Dikoglou C, Bramis J: Postchemotherapy resection of a primary mature malignant retroperitoneal teratoma in an adult: report of a case. Surg Today 2005;35:965-967.

11 Song ES, Choi SJ, Kim L, Choi SK, Ryu JS, Lim MK, Song YS, Im MW: Mucinous adenocarcinoma arising from one retroperitoneal mature cystic teratoma in a postmenopausal woman. J Obstet Gynaecol Res 2005;31:127-132.

12 Joseph LD, Devi MK, Sundaram S, Rajendiran S: Squamous cell carcinoma arising from primary retroperitoneal mature teratoma. J Assoc Physicians India 2007;55:374-376.

13 Chu PY, Teng TH, Lee CC, Chou YY: Adenocarcinomas arising from primary retroperitoneal teratoma in an adult female patient. Int J Urol 2006;13:1352-1354.

$\checkmark 14$ Cheung WL, Cao D: Colonic-type adenocarcinoma arising in a primary retroperitoneal mature cystic teratoma. Pathol Int 2008;58:792-796.

15 Kim JH, Lee TS, Oh HK, Choi YS: A case of mucinous adenocarcinoma arising from retroperitoneal teratoma treated with chemoradiation. J Gynecol Oncol 2009;20:126-128.

-16 Terado Y, Kurata A, Ishida T, Imamura T, Sakamoto A: Adenocarcinoma of small intestinal type in retroperitoneal mature teratoma. Pathol Int 2010;60:701-705. 